Dept. of Food Hygiene,

Animal Health Research Institute, Alexandria, Egypt.

\title{
DETERMINATION OF CHEMICAL PARAMETERS OF BEEF AND ITS PRODUCTS
}

(With One Table)

\author{
By \\ MERVAT KAMAL IBRAHIM RAGAB
}

(Received at 12/9/2011)

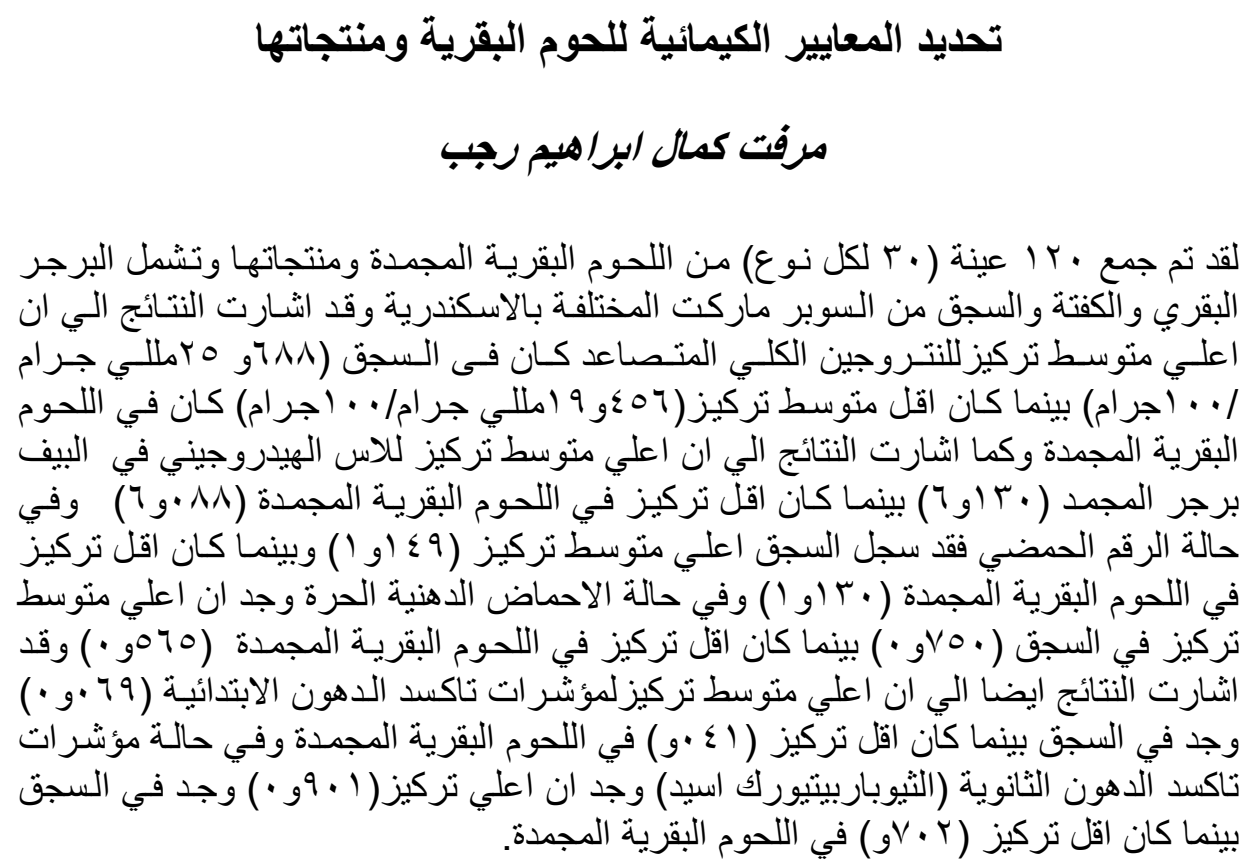

\section{SUMMARY}

A total of 120 samples of frozen beef and its products (beef burger, kofta and sausage), 30 samples of each, were collected from different supermarkets in Alexandria governorate to evaluate their chemical quality. The results revealed that the highest mean total volatile nitrogen (TVN) $(25.688 \mathrm{mg} / 100 \mathrm{gm})$ was found in sausage samples while the lowest $(19.456 \mathrm{mg} / 100 \mathrm{gm})$ was in frozen beef meat samples. Concerning $\mathrm{pH}$, beef burger samples showed the highest mean levels (6. 130) while frozen beef samples had the lowest (6.088). In case of 
acid value, sausage had the highest mean concentration $(1.149 \mathrm{mgkoH}$ /gm of fat) while, frozen beef samples showed the lowest value (1.130 mgkoH /gm). Rgarding free fatty acids, the highest mean concentration $(0.750 \mathrm{ml} / \mathrm{gm})$ was found in sausage while the lowest $(0.565 \mathrm{ml} / \mathrm{gm})$ was in frozen beef samples. In case of conjugated dienes (CD), the highest level $(0.069 \mathrm{n}$ mole $/ \mathrm{mg})$ was in sausage samples while the lowest $(0.041$ $\mathrm{n}$ mole/mg) was in frozen beef. Concerning thiobarbeturic acid value (TBA), sausage also showed the highest level $(0.901 \mathrm{mg}$ malonaldhyde $/ \mathrm{kg}$ of sample) while frozen beef samples showed the lowest $(0.7018 \mathrm{mg}$ malonaldhyde $/ \mathrm{kg}$ of sample).

Key words: Beef, beef products, $p H$, TVBN, thiobarbeturic acid.

\section{INTRODUCTION}

Food spoilage means the original nutritional value, texture, flavour of the food are damaged, the food become harmful to people and unsuitable to be consumed. (Nuray Erkan et al., 2005; Mahmoudzadeh et al., 2010). There are different Causes of spoilage of food. The most important are Microbial spoilage (there are three types of microorganisms that cause food spoilage (yeasts, moulds and bacteria), Autolysis, by Enzymes (they are proteins found in all plants and animals), and Atmospheric oxygen which can react with some food components that may cause rancidity or color changes (Jay, 2000; Koutsoumanis et al., 2006; Pavlov, 2007).

It is known that during storage, the oxidative and hydrolytic processes that occur in both lipid and protein fractions of meat are one of the major causes for changes in its quality parameters. Lipid oxidation is often responsible for quality loss via formation of rancid flavour and is affected by the duration and temperature of storage of meat, as well as the presence of oxygen. During chilled and frozen storage lipid oxidation is usually slow but does not stop since the reactive species are soluble in the lipid fraction and stable at low temperatures. Protein oxidation produces different amino acid modifications leading to carbonyl formation and decreased sulfhydryl content that alter the water holding capacity and tenderness of meat as well as its nutritional value. The amounts of malondialdehyde (MDA) increased during chilled storage with significant difference between the 1 st and the $6^{\text {th }}$ day $(\mathrm{P}<0.05)$. The subsequent freezing of the meat resulted in higher values of the TBARS on the 90th day of storage which were significantly 
different $(\mathrm{P}<0.001)$. The amounts of MDA formed during chilled storage were in the range $0.17-0.32 \mathrm{mg} / \mathrm{kg}$ meat and reached $0.64 \mathrm{mg} / \mathrm{kg}$ meat on the $90^{\text {th }}$ day. Development of lipid oxidation during storage in nonvacuum packaged beef meat. Points, connected with different letters are statistically different. Time had significant influence $(\mathrm{P}<0.01)$ on the development of oxidation in vacuum packaged beef similarly to the non vacuum packaged. Significant difference was observed between the amounts of the TBARS measured on 1st and 2nd $(\mathrm{P}<0.05)$ and $2 \mathrm{nd}$ and 6th days $(\mathrm{P}<0.01)$ due to the drop of the formation of MDA in the first interval of storage. Its content varied between $0.61-0.72 \mathrm{mg} / \mathrm{kg}$ meat. It was found that the type of storage had significant effect on the lipid oxidation development $(\mathrm{P}<0.001)$. Unexpectedly vacuum packaged samples showed higher content of TBARS when subsequently chilled, compared to the non vacuum packaged meat as the difference was significant on the 1 st and $6^{\text {th }}$ day of storage $(\mathrm{P}<0.001$ In both non vacuum and vacuum packaged meat, the amounts of TBARS formed in the course of storage were far below the critical value of $3 \mathrm{mg} / \mathrm{kg}$ at which rancidity is detected. It could be supposed that the low intensity of oxidative processes was due to the raising mode of the studied animals which provided natural antioxidants, such as vitamin E, carotenoids, (Teodora et al., 2009).

It was indicated that meat (beef) owes its perishability to its high water content and preponderance of nutrients such as high molecular proteins, low molecular substances such as glucose, free amino acids, peptides and very minute amount of glycogen (Reginaldo et al., 2007). The major biochemical processes and products that affect meat quality include glycogen breakdown, rigor mortis, glycolysis, proteolysis, oxidation and lipolysis. Ultimate $\mathrm{pH}$ and fatty acid quality are, arguably, the major factors that influence meat eating quality. These are affected by pre-slaughter handling of the cattle and post-slaughter handling of the meat), care and state of animal, age, sex, species, hygiene precautions in the slaughter house (Anon, 2001; Muchenje et al., 2009; Constantin and Cornel, 2010). In a situation when a cow is well rested before slaughter, its post-rigor $\mathrm{pH}$ of 5.4 is achieved. Further changes (chemical, microbial and organoleptic), depending upon prevailing or storage temperature, relative humidity, bulkiness of meat, degradation of low molecular substances by the activity of the dominant indigenous microorganisms, are also overt (Ellis and Goodacre, 2001; Koutsoumanis et al., 2006; Geogorge et al., 2008). 
Immediately post-mortem the muscle contains a small amount of muscle specific carbohydrate, called glycogen ${ }^{1}$ (about $1 \%$ ), most of which is broken down to lactic acid in the muscle meat in the first hours (up to 12 hours) after slaughtering. This biochemical process serves an important function in establishing acidity (low $\mathrm{pH}$ ) in the meat. The socalled glycolytic cycle starts immediately after slaughter in the muscle tissue, in which glycogen, the main energy supplier to the muscle, is broken down to lactic acid. The build up of lactic acid in the muscle produces an increase in its acidity, as measured by the $\mathrm{pH}$. The $\mathrm{pH}$ of normal muscle at slaughter is about 7.0 but this will decrease in meat. In a normal animal, the ultimate $\mathrm{pH}$ (expressed as $\mathrm{pH}_{24}=24$ hours after slaughter) falls to around $\mathrm{pH}$ 5.8-5.4. The degree of reduction of muscle $\mathrm{pH}$ after slaughter has a significant effect on the quality of the resulting meat (FAO, 2007). From the point of view of routine quality control, measurements of $\mathrm{pH}$ appear to be useful for spoilage assessment. The $\mathrm{pH}$ of the meat should preferably not exceed about 6.0 (Mohd et al., 2010). Post-slaughter changes in meat should be submitted to technological control, as muscle tissue undergoes structural changes typical to all cells with stopped metabolism. Muscles, initially relaxed and elastic, gradually become hard and stiff, till attaining complete stiffness. As oxygen is no longer supplied, accumulation of carbon dioxide and lactic acid occurs, increasing hydrogen cations concentration, so that muscle $\mathrm{pH}$ gets reduced from 7.4 to 5.5. Such reduced $\mathrm{pH}$ restricts anaerobic processes and inhibits enzymes involved in these processes. Due to activation of proteolytic enzymes, meat becomes soft and tender (Grzegorz et al., 2010).

It has been reported that development of spoilage is related to metabolization of meat's low molecular substances, such as sugar and free amino acids and the release of undesirable volatile metabolites. As soon as the glucose present in aqueous phase has been exhausted other substrates are consequently utilized by metabolizing microorganisms to produce odoriferous nitrogenous compounds, (Dainty et al., 1985; Jay, 2000).

During the formation of primary oxidation products (hydroperoxides) from unsaturated fatty acids, conjugated dienes are typically produced, due to the rearrangement of the double bonds. The resulting conjugated dienes exhibit an intense absorption at $234 \mathrm{~nm}$; similarly conjugated trienes absorb at $268 \mathrm{~nm}$. An increase in UV absorption theoretically reflects the formation of primary oxidation products in fats and oils. The primary oxidation products 
(hydroperoxides) are unstable and susceptible to decomposistion. A complex mixture of volatile, nonvolatile, and polymeric secondary oxidation products is formed through decomposition reactions, providing various indices of lipid oxidation. Secondary oxidation products include aldehydes, ketones, alcohols, hydrocarbons, volatile organic acids, and epoxy compounds, among others (Gambacorta et al., 2009).

The thiobarbituric acid (TBA) test was proposed over 40 years ago and is now one of the most extensively used methods to detect oxidative deterioration of fat-containing foods. During lipid oxidation, malonaldehyde (MA), a minor component of fatty acids with 3 or more double bonds, is formed as a result of the degradation of polyunsaturated fatty acids. It is usually used as an indicator of the lipid oxidation process, both for the early appearance as oxidation occurs and for the sensitivity of the analytical method. In this assay, the MA is reacted with thiobarbituric acid (TBA) to form a pink MA-TBA complex that is measured spectrophotometrically at its absorption maximum at 530-535 $\mathrm{nm}$. The extent of oxidation is reported as the TBA value and is expressed as milligrams of MA equivalents per kilogram sample or as micromoles of MA equivalents per gram of sample. The TBA test provides an excellent means for evaluating lipid oxidation in foods, especially on a comparative basis (Sallam and Samejima, 2004).

Total volatile basic amines (TVB) is one of the most widely used measurements of meat quality. It is a general term which includes the measurement of trimethylamine (produced by spoilage bacteria), dimethylamine (produced by autolytic enzymes during frozen storage), ammonia (produced by the deamination of amino-acids and nucleotide catabolites) and other volatile basic nitrogenous compounds associated with food spoilage. Although TVB analysis are relatively simple to perform, they generally reflect only later stages of advanced spoilage However, it should be kept in mind that TVB values do not reflect the mode of spoilage (bacterial or autolytic), and results depend to a great extent on the method of analysis(Goulas and Kontaminas, 2005).

Sensory and microbiological analyses are most often used to evaluate the quality of meat. The disadvantages of sensory analysis, is its reliance on highly trained panellists, which makes it costly and unattractive for routine analysis. On the other hand, micro- biological analysis, either with traditional numbers (e.g., total viable) or with the use of molecular tools (PCR, RT-PCR, DGGE) are often misleading and scientists have shown that it is more meaningful to measure the responsible for spoilage microflora fraction. Of course, in most cases sensory 
methods are useful for identifying products of very good or poor quality. Thus, biochemical/ chemical methods may best be used in resolving issues regarding products of marginal quality. Unfortunately, microbiological analyses are lengthy (tradi- tional, conventional microbiology), costly and high-tech (molecular tools), and destructive to test products; therefore, efforts have been made to replace both microbiologi- cal and sensory analyses with biochemical changes occurring in muscle (e.g., various microbial metabolic products, termed as chemical spoilage indices - CSI), that could be used to assess meat spoilage (George et al., 2008). Sine frozen meat is perishable food and susceptible to spoilage, so, the purpose, of this study was to evaluate the quality of frozen meat and its products using chemical methods

\section{MATERIALS and METHODS}

A total of 120 samples of imported frozen beef and its products (beefburger, kofta and sausage were selected randomly from different supermarkets in Alexandria (30 samples for each). Samples were transported in an insulated ice box to the laboratory and analyzed for chemical quality parameters.

\section{Determination of chemical quality parameters:}

1- Total volatile nitrogen: it was determined by steam distillation method (Malle and pourmeyrol, 1998).

2- Hydrogen ion concentration $(\mathrm{pH})$ : it was estimated according to AOAC (1980).

3- Acid number: It is defined as the number of milligrams of $\mathrm{KOH}$ required to neutralized the free acid in 1 gram of sample. It was determined according to Pearson (1976).

4- Free fatty acids were determined according to Pearson (1976).

5- Conjugated dienes were determined according to Santiago et al. (1997).

6- Thiobarbeturic acid (TBA) was determined colourimetrically according to Li et al. (2001). 


\section{RESULTS}

Table 1: Mean values \pm S.D of chemical quality parameters of the examined frozen beef meat samples and its products (beef burger, kofta and sausage)

\begin{tabular}{|c|c|c|c|c|}
\hline \multirow{2}{*}{ Chemical parameters } & \multicolumn{3}{|c|}{ Type of samples } \\
\cline { 2 - 5 } & $\begin{array}{c}\text { Frozen beef } \\
\text { Mean } \pm \text { S.D }\end{array}$ & $\begin{array}{c}\text { Beef burger } \\
\text { Mean } \pm \text { S.D }\end{array}$ & $\begin{array}{c}\text { Kofta } \\
\text { Mean } \pm \text { S.D }\end{array}$ & $\begin{array}{c}\text { Sausage } \\
\text { Mean } \pm \text { S.D }\end{array}$ \\
\hline Total volatile nitrogen (TVN) & $19.456 \pm 0.523$ & $21.879 \pm 1.283$ & $24.309 \pm 1.943$ & $25.688 \pm 1.412$ \\
\hline $\begin{array}{c}\text { Hydrogen ion concentration } \\
\text { (pH) }\end{array}$ & $6.088 \pm 0.120$ & $6.216 \pm 0.100$ & $6.206 \pm 0.190$ & $6.131 \pm 0.370$ \\
\hline Acid value (AV) & $1.130 \pm 0.135$ & $1.324 \pm 0.120$ & $1.409 \pm 0.100$ & $1.4996 \pm 0.01$ \\
\hline Free fatty acids (FFA) & $0.565 \pm 0.268$ & $0.662 \pm 0.326$ & $0.705 \pm 0.158$ & $0.750 \pm 0.261$ \\
\hline Conjugated dienes (CD) & $0.041 \pm 0.011$ & $0.049 \pm 0.0212$ & $0.064 \pm 0.023$ & $0.069 \pm 0.023$ \\
\hline Thiobarbeturic acid (TBA) & $0.7018 \pm 0.127$ & $0.8226 \pm 0.286$ & $0.863 \pm 0.267$ & $0.9010 \pm 0.218$ \\
\hline
\end{tabular}

\section{DISCUSSION}

Chemical quality parameters of the examined frozen beef meat samples and its products were recorded in Table 1. Beef products (beef burger, kofta and sausage) showed higher levels of all chemical parameters than frozen beef. Concerning the total volatile nitrogen (T.V.N.), the highest mean value was found in sausage samples $(25.688 \mathrm{mg} / 100 \mathrm{gm})$ while the lowest was in frozen beef samples $(19.456 \mathrm{mg} / 100 \mathrm{gm})$ with no significant difference between them (Table 1). These results was in agreement with results of different authors like Mansour and Basha (2009) who found that the total volatile basic nitrogen (T.V.B.N.) of samples of imported frozen boneless beef of different cuts that collected from different markets of Alexandria were within the permissible limits. Mahmoud et al. (1987) reported that the addition of broken white rice and decorticated faba bean flours, as meat substitutes in beefburger cause a slight and gradual increase in total volatile nitrogen (T.V.B.N) during frozen storage at $-22^{\circ} \mathrm{C}$ for 3 months 
and Basem (2004) stated that the total volatile nitrogen content of beef and lamb mortadella samples stored for 16 weeks under refrigeration were within the standard permissible limits.

Ammonia, determined as T.V.B.N, may be used as an index of meat quality under chill temperature according to the scheme of Pearson (1975) showing meat's fresh to be 13 and its acceptable value to be $\leq 17$. In this report it was evident that beef storage for 4 days at 1-20C and barely 3 days at $5-70 \mathrm{C}$ is acceptable for human consumption. However, in four days TVBN values of 23.8 at $1-20 \mathrm{C}$ in 2 days and TVBN 20.9 are adjudged fit for human consumption being odourless, non-slimy and non-putrid. All the parameters used to determine the wholesomeness of meat under chill conditions seem to have worked in consonance. (Agunbiade et al., 2010).

Pearson (1968) recorded a steady increase in TVBN levels during storage of beef and lamb fat free and showed that raw beef was acceptable with respect to odour when TVBN levels did not exceed 16.5 and $19.7 \mathrm{mg}$ per $100 \mathrm{~g}$, measured on lean meat and fat-free meat, respectively. However, while this may be the case in fresh meat, it may not apply in cured meat products, such as mortadella, as the latter contains other ingredients that may mask the off-odour caused by a high level of TVBN and be still acceptable when judged on a basis of sensory evaluation. (Basem, 2004).

Changes in the quality of minced beef were studied under two refrigerated conditions (1-20C and 5-70C) using some biochemical assays during a six-day period increased total volatile nitrogen (TVN) from $12.6 \mathrm{mgN} / 100 \mathrm{~g}$ protein in the fresh state to between $23.8 \mathrm{mgN} / 100 \mathrm{~g}$ protein and $39.8 \mathrm{mgN} / 100 \mathrm{~g}$ protein under the two chill temperatures (Dainty et al., 1985; Standbridge and Davies, 1998).

Our results indicated that beef burger samples showed the highest mean levels of hydrogen ion concentration (6.216) while frozen beef samples showed the lowest level (6.088), with no significant difference between them as shown in Table 1. This results was coincide with that of Basem (2004) who reported that The $\mathrm{pH}$ values of Beef and lamb mortadella samples that were prepared under controlled conditions and stored for 16 weeks under refrigeration was relatively high, attributable to addition of sodium polyphosphate.

It was reported that $\mathrm{pH}$ of samples of imported frozen boneless beef of different cuts that collected from different markets of Alexandria were within the permissible limits. (Mansour and Basha et al., 2009). 
The gradual increase of meat's $\mathrm{pH}$ from 5.4 in fresh state to 5.8 at $1-20 \mathrm{C}$ in 5 days and 5.7 at $5-70 \mathrm{C}$ in 3 days, and its subsequent pronounced increase to between 6.1 and 6.9 may be ascribed to proteolysis on one hand. Minced meat for use in hamburger, corn beef, hot dog and other meat products may enjoy a shelf stability of only 3 day holding period under chill temperatures otherwise it is deemed unsafe for human consumption. The gradual but consistent rise in the degree of meat's alkalinity as storage and spoilage progressed may be due to production and accumulation of odoriferous nitrogenous compounds, most predominantly ammonia (Dainty et al., 1985; Standbridge and Davies, 1998).

It was found that sausage samples had the highest mean concentration of acid value (1.149) while the lowest was in frozen beef samples (1.130). In case of free fatty acids, the highest mean concentration $(0.750)$ was found in sausage while the lowest $(0.565)$ was in frozen beef samples (Table 1).

Lipolysis is one of the main processes of lipid degradation in fresh meat during processing and is regulated by a set of specific enzymes, namely lipases and phospholipases, thus leading to the formation of free fatty acids (FFAs). Both endogenous enzymes of fat cells and muscle fibers and bacterial enzymes are involved in lipolysis. In fat cells of both adipose tissues and muscle and in muscle fibers, triacylglycerols (TAGs) are hydrolyzed by two important lipase systems: lipoprotein lipase and hormone-sensitive lipase producing FFAs, monoacylglycerols (MAGs) and diacylglycerols (DAGs). Although the activity of these lipases decreases during the dry-curing process, these enzymes remain active during the entire process for dry sausages and a large part of process for production of dry-cured hams. FFAs, produced by endogenous lipolysis, undergo enzymatic oxidation which promotes the production of some aromatic compounds (ketones, aldehydes, etc.) responsible for the typical organoleptic properties in meat products (Gambacorta et al., 2009). It is suggested that for minced beef meat in retail establishment, a maximium FFA value during storage is suggested to be $1.8 \%$ (Pearson, 1976).

The increase of free fatty acids during maturation of Mediterranean and North Europe type sausages appears to be independent from processing conditions and the differences in polyunsaturated fatty acids increment found among the formulations appear to be due to inherent variations of raw materials. The effect on fatty acid oxidation of the same additives and of the different processing 
technologies is not significantly different and the variations linked to raw material may play the greatest role (Emanuela et al., 2004).

Regarding conjugated dienes, the highest level (0.069) was in sausage samples while the lowest $(0.041)$ was found in frozen beef samples. In case of T.B.A, sausage samples showed the highest mean concentrations (0.9010) while the lowest was in frozen beef samples (0.7018), (Table 1). These results a gree with that of Larsen et al. (1986) who recorded a consistent increase in oxidative rancidity in meat products proportional to the amount of malonaldehyde produced. Basem (2004), found that the TBA value, for both beef and lamb mortadella samples prepared under controlled conditions and stored for 16 weeks under refrigeration was $0.61 \mathrm{mg} \mathrm{kg}$ ) 1 in week 1 , increasing to $0.82 \mathrm{mg}$ $\mathrm{kg}) 1$ for beef and $2.0 \mathrm{mg} \mathrm{kg}$ ) 1 for lamb in week 16 of storage.

TBA value is often used as an index of lipid oxidation in meat products during storage, the TBA number at which rancid odor was first perceived was between 0.5 and 1.0. This threshold has served as a guide for interpreting TBA test results (Sallam ${ }^{\mathrm{a}^{*}}$ and Samejima, 2004).

It was reported that there is no difference in TBA values of meat products treated with sodium lactate $(\mathrm{NaL})$ in comparison with controls (Eckert et al., 1997; Lin and Lin, 2002; Vasavada et al., 2003). Some authors indicated that meat products treated with sodium lactate $(\mathrm{NaL})$ had an antioxidant effect represented by decrease in TBA values (Nnanna et al., 1994; Maca et al., 1999).

\section{Conclusions and Recommendations:}

We can conclude that:

1- Frozen beef samples were of better chemical quality than its products (beef burger, kofta and sausage), with special reference to oxidative changes. This may be due to the effect of chemically reactive oxygen which can show detrimental oxidative changes in beef and beef products during processing and storage.

2- Combination of several measures is necessarary in order to safe guard product during its shelf life. These measures include oxygen exclusion in vacuum orMAP (modified atmospheric packaging) packaging the use of natural antioxidants in feed of animals or during processing, ascorbic acid (vitamin c), vitamin E or phosphates and citrates or the addition of synthetic antioxidants. 


\section{REFERENCES}

Agunbiade, S.O.; Akintobi, O.A. and Ighodaro, O.M. (2010): Some Biochemical organoleptic changes due to Microbial growth in Minced Beef packaged in Alluminium polyethylene trays and Stored under Chilled condition. Life Science Journal. 7(2): $47-51$.

ANON (2001): Ingredients in Processed Meat Product: Montana Meat Processors Convertion April 27-29, 2001. Basic Chemistry of Meat.

AOAC "American Association of official analytical chemists" (1980): Official M. A. $13^{\text {th }}$ ed., AOAC, Arlinoblon, V.A.N

Basem Moh'd Abdullah (2004): Beef and sheep mortadella: formulation, processing and quality aspects . International Journal of Food Science and Technology 39: 177-182 .

Constantin Moldovanu, and Cornel Laslo, (2010): Physicochemical and microbiological research on characteristics of meat products during storage in the membrane depending on the quality of raw materials. ABAH Bioflux, 2, 2: 65-68.

Dainty, R.H.; Edwards, R.A. and Hibbard, C.M. (1985): The Time Course of Volatile Compounds Formation during refrigerated storage of naturally contaminated beef in air. J. Appl. Bacteriol. 59: 303-309.

Eckert, LA.; Maca, JV.; Miller, RK. and Acuff, GR. (1997): Sensory, microbial and chemical characteristics of fresh aerobically stored ground beef containing sodium lactate and sodium propionate. Journal of Food Science 1997; 62: 429-433.

Ellis, D.L. and Goodcre, R. (2001): Rapid and quantitative detection of the microbial spoilage of muscle foods: Current status and future trends. Trends Food Sci. Technol. 12: 414-424.

Emanuela Zanardi*, Sergio Ghidini, Alessandra Battaglia and Roberto Chizzolini, (2004): Lipolysis and lipid oxidation in fermented sausages depending on different processing conditions and different antioxidants. Meat Science 66: 415-423.

FAO (2007): Meat Processing Technology for small-to medium-Scale producers. Gunter Heinz., Peter Hautzinger Regional Office for ASIA and the Pacific Banckoke.

George-John E. Nychas; Panos., N.; Skandamis, Chrysoula, C.; Tassou, Konstantinos, P. and Koutsoumanis, (2008): Meat spoilage during distribution. Meat Science 78: 77-89. 
Goulas, A.E. and Kontaminas, M.G. (2005): Effect of salting and smoking method on the keeping quality of chub mackerel (Scomber japonicus): Biochemical and sensory attributes. Food Chem., 93: 511-520.

Gambacorta, G.M.; Sinigaglla, A.; Schenal, A.; Balano, Lamacchla, S. Patli, and LA Nottei, E. (2009): Changes in free fatty acid and diacylglycerol compounds in short-ripening dry-cured sausage Journal of Food Lipids 16: 1-18.

Jay, J.M. (2000): Food preservation with modified atmospheres, p. 283295. In D.R. Heldman (ed.), Modern Food Microbiology. Aspen Publishers, Inc. Gaithersburg, Md.

Koutsoumanis, K.; Stamation, A.; Skandamis, P. and Nychas, J.G. (2006): Development of microbial model of temperature and $\mathrm{pH}$ on spoilage of ground beef and validation of the model under dynamic temperature conditions. Appl. Environ. Microbiol. 72: 124-134.

Li, C.T.; Wick, M. and Marriottm, N.G. (2001): Evaluation of lipid oxidation in animal fat. Bull Ohio State University, Research and Reviews: meat special circular, 172: 99-104.

Larsen, J.E.; Macneil, J.H. and Mast, M.G. (1986): Sensory and quality characteristics of poultry frankfurters containing nitrite and sorbate. Poultry Science, 65: 1542-1546.

Lin., K.W. and Lin., S.N. (2002): Effects of sodium lactate and trisodium phosphate on the physicochemical properties and shelf life of low-fat Chinese-style sausage. Meat Science. 60: 147-154.

Malle and poumeryrol (1998): A new chemical criterion for the quality control of fish: TMA/TVBN (\%). J. Food Protection 52(6): 419-423.

Mansour, A.F.A. and Basha, O.A.M. (2009): Hygienic status of imported frozen beef in Alexandria markets. Journal of Assiut Veterinary Medical Journal 55, 121: 162-171.

Mahmoud, A. Hamza; Yehia, G. Moharram; Mohamed, B. Aman and Magdi, O. El-Akary (1987): Frozen storage stability of beefburger containing plant meat substitutes Food Chemistry. 26: 261-269.

Mahmoudzadeh, M.1.; Motallebi, A.A.; Hosseini, H.1.; Haratian, P.1.; Ahmadi, H.1.; Mohammadi, M.1. and Khaksar, R. (2010): Quality assessment of fish burgers from deep flounder (Pseudorhombus elevatus) and brushtooth lizardfish 
(Sauridaundosquamis) during storage at $-18^{\circ} \mathrm{C}$. Iranian Journal of Fisheries Sciences, 9(1) 111-126 20,10.

Muchenje, V.K.; Dzama, C.; Chimonyo, M.; Strydom, P.E.; Hugo, A.; and Raats, J.G. (2009): Some biochemical aspects pertaining to beef eating quality and consumer health: A review., Food Chemistry 112: 279-289.

Maca, JV.; Miller, RK.; Bigner, ME.; Lucia, LM. and Acuff, GR. (1999): Sodium lactate and storage temperature effects on shelf life of vacuum packaged beef top rounds. Meat Science 23-29.

Nnanna, IA.; Ukuku, DO.; McVann, KB. and Shelef, LA. (1994): Antioxidant activity of sodium lactate in meat and model systems. Food Science and Technology 27: 78-85.

Nuray Erkan, (2005): Changes in qualitycharacteristics during cold storage of shucked mussels (Mytilus galloprovincialis) and selected chemical decomposition indicators. J. Sci. Food Agric. 85: 2625-2630.

Nuchas, G.J.E.; Skandamis, P.N.; Tassau, C.C. and Koutscumanis, K.P. (2008): Meat spoilage during distribution, Meat Science 78: 77-87.

Pavlov, A. (2007): Changes in the meat from aquaculture species during storage at low temperature and attempets for differentiation between thawed frozen and fresh chilled meat. A review., Bulgarian Journal of Veterinary Medicine 10, 2: 67-75.

Pearson,D. (1976): Laboratory techniques in food analysis, London, Boston,Butter worth, Co. Ltd.1978,51-75.

pearson, D. (1968): Application of chemical methods for the assessment of beef quality II. Methods related to protein breakdown. Journal of the Science of Food and Agriculture, 19: 366-369.

Pearson, D. (1975): Laboratory Techniques Series. Laboratory Techniques pp. 169-172 in Food Analysis, London and Boston Butterworth.

Reginaldo, A.; Trindade, Jorge Mancini-Filho; Ingrid, T. Sabundjian; Thaise, C.F. Nunes; Vladimir, D. Rogovschi; Anna Lúcia, C.H. and Villavicencio, (2007): Changes on lipid profile in beef burgers prepeared with rosmary extract. International Nuclear Atlantic Conference - INAC 2007 Santos, SP, Brazil, September 30 to October 5, 2007. Associacao Brasileira De Energia Nuclear-Aben ISBN: 978-85-99141-02-1. 
Santiago, P. Aubourg; Caemen, G. and Jose, M. (1997): Assessment of Quality Changes in Frozen Sardine (Sardina pilchardus) by Fluorescence Detection. European Food Research and Tchnology. 62(2): 295-298.

Standbridge, L.H. and Davies, A.R. (1998): The microbiology of chillstored meat, p. 175-177. In A. Davies and R. Board (ed.), Microbiology of meat and poultry. Blackie Academic and Professional, London, United Kingdom.

Sallam, Kh.I. and Samejima, K. (2004): Microbiological and chemical quality of ground beef treated with sodium lactate and sodium chloride during refrigerated storage. Lebenson Wiss Technol. 37(8): 865-871.

Teodora Popova; Penka Marinova; Veselka Vasileva, Y. Gorinov; Krasimira Lidji, (2009): Oxidative changes in lipids and proteins in beef during storage. Archiva Zootechnica 12, 3: 30-38.

Vasavada, M.; Carpenter, C.E.; Cornforth, D.P. and Ghorpade, V. (2003): Sodium levulinate and sodium lactate effects on microbial growth and stability of fresh pork and turkey sausages. Journal of Muscle Foods. 14: 119-129. 